\title{
Craniofacial features of operated unilateral complete cleft lip and palate children: a case control study
}

\author{
Crescimento maxilo-mandibular em crianças com fissura unilateral completa de lábio e palato reparada: \\ estudo caso controle
}

Renata Cristina Suzin ROMANINI ${ }^{1}$

Silvia VEDOVELLO ${ }^{1}$

Ricardo RAITZ 1

Milena Bortolotto Felippe SILVA ${ }^{1}$

José Luiz Cintra JUNQUEIRA ${ }^{1}$

Luciana Butini OLIVEIRA'

\section{ABSTRACT}

\section{Objective}

To compare the craniofacial features of Brazilian children who had received surgery for unilateral complete cleft lip and palate compared with non-cleft group.

\section{Methods}

Craniofacial features were evaluated on lateral cephalometric radiographs. 46 patients with unilateral complete cleft lip and palate were divided by gender and matched at ages 6, 7, 8 and 9. They were compared with 46 non-cleft children, equally divided by gender and matched the same age groups. All comparisons were carried out by means of the Angles SNA, SNB and ANB. The findings were analyzed on the basis of the two-way Analysis of Variance (ANOVA) with $p<0.05$ significance level.

\section{Results}

Both the angle SNA and SNB in the cleft group had a lower average in both genders and all age groups compared with the non-cleft group $(p<0.0001)$. The average values of ANB were significantly higher in the cleft group $(p<0.05)$ both in males and females and in all age groups studied.

\section{Conclusion}

Children who had received surgery for unilateral complete cleft lip and palate during childhood had maxillary and mandibular retrusion and a class II skeletal pattern in relation to non-cleft group.

Indexing terms: Child. Cleft lip. Cleft palate. Maxillofacial development.

\section{RESUMO}

\section{Objetivo}

Comparar o crescimento ântero-posterior da maxila e da mandíbula entre pacientes com fissura unilateral completa de lábio e palato reparada e pacientes que não apresentavam nenhuma alteração craniofacial.

\section{Métodos}

Foram selecionadas 46 telerradiografias cefalométricas em norma lateral de pacientes com fissura unilateral completa de lábio e palato que foram submetidos às cirurgias primárias de correção durante a infância (grupo de estudo). A amostra do grupo controle foi composta por 46 telerradiografias cefalométricas em norma lateral de pacientes sem nenhuma alteração craniofacial e que apresentavam valores para os ângulos SNA e SNB dentro dos valores pré-estabelecidos de normalidade. O gênero e as faixas etárias entre 6 e 9 anos dos pacientes foram pareados e comparados em ambos os grupos. A comparação entre os dois grupos foi realizada por meio dos ângulos SNA, SNB e ANB. Aplicouse a análise de variância (ANOVA), considerando-se o nível de significância de 5\%.

\section{Resultados}

Observou-se diferença significativa entre os grupos de pacientes com fissura reparada e controle ( $p<0,0001)$, ou seja, o grupo com fissura reparada apresentou menor média de SNA e SNB em todas as idades. Para o ângulo ANB, o grupo com fissura reparada apresentou maior média em todas as faixas etárias $(p<0,05)$.

\section{Conclusão}

Pode-se concluir que o grupo de pacientes com fissura unilateral completa de lábio e palato reparada nas faixas etárias estudadas e em ambos os gêneros apresentaram maxila e mandíbula retruídas em uma relação esquelética de Classe ll em relação ao grupo controle.

Termos de indexação: Criança. Fenda palatina. Fissura palatina. Desenvolvimento maxilofacial.

\footnotetext{
${ }^{1}$ Faculdade São Leopoldo Mandic. Rua José Rocha Junqueira, 13, Swift, 13045-755, Campinas, SP, Brasil. Correspondência para / Correspondence to: LB OLIVEIRA. E-mail: <luciana.butini@slmandic.edu.br>.
} 


\section{INTRODUCTION}

The cleft lip and palate are the most common congenital facial malformations in newborns ${ }^{1-2}$. These changes can be divided into distinct groups: cleft lip, cleft lip and palate and cleft palate ${ }^{2-3}$. The treatment of patients with cleft may begin soon after birth with the use of presurgical orthopedic apparatus, which the main objective is to assist the surgeon in cheiloplasty ${ }^{4}$ (lip closure surgery, typically performed at 6 months of age) and palatoplasty ${ }^{1}$ (closure of the palate surgery, usually performed after 12 months of age), although there are 171 clinical protocols for treating these patients ${ }^{5}$.

Although there are previous studies on craniofacial development and morphology in children with clefts, these studies lacked elucidation about the effect of primary surgery on craniofacial development in unilateral complete cleft lip and palate. The knowledge of developmental dental disorders in cleft lip and palate children can provide valuable information for treatment planning at an early age $^{6-7}$. A recent study concluded that operated unilateral complete cleft lip and palate children showed serious craniofacial deformities and the craniofacial growth was influenced especially in maxilla ${ }^{8}$, but no true consensus has been reached at this time about the influence of surgery on facial growth. Some studies of adolescent and adult patients with unoperated unilateral cleft lip alveolus and palate indicate that they have a normal potential for maxillofacial growth ${ }^{9-10}$.

In Brazil, the prevalence of orofacial clefts was 0.36 per 1.000 live births and there was a proportion of this occurrence in 1.6 men for every female ${ }^{11}$. Because the findings about the effect of surgery during childhood on craniofacial development are equivocal and there is only one previous comparative study in Brazilian children ${ }^{12}$, this study was carried out. The aim of this case control study was to analyze the craniofacial features of Brazilian children who had received surgery for unilateral complete cleft lip and palate compared with non-cleft group.

\section{METHODS}

The study was performed on standardized lateral cephalograms obtained at the CAIF's Maxillofacial Surgery Service, located in the city of Curitiba, Paraná, Brazil. The study sample comprised a total of 92 Brazilian children aged between 6 and 9 years divided into operated children with unilateral complete cleft lip and palate (study group) and non-cleft children (control group).
Inclusion criteria for the cleft group was the existence of unilateral complete cleft lip and palate, the presence of mixed dentition in the age group between 6 and 9 years and primary surgeries for correction of the lip (cheiloplasty) between 3 and 6 months of life and for correction of the palate (palatoplasty) from 12 to 18 months of age. The patients were submitted to surgical interventions according to CAlF's protocol. Exclusion criteria were the presence of syndromes and the use of any history of orthodontic apparatus. The control group was comprised of 46 patients. They were selected for this group $(\mathrm{CG})$, being considered for inclusion was the absence of any type of cleft, the presence of mixed dentition in age from 6 to 9 years of age and SNA and SNB values of the standard considered acceptable. It was agreed SNA angle to the default value of 82 , with a variation of $+/-2^{\circ}$ and SNB, the value of 80 , with a variation of $+/-2^{\circ}$. The exclusion criterion was the use of any history of orthodontic apparatus.

All tracings were performed two times by one trained observer (RCSR) without knowing age or gender, with a difference of 30 days between each other, resulting in two values for each cephalometric variable. The values used for this study were those obtained from the simple arithmetic average of two measures For the measurement of angles SNA, SNB and ANB (Figure 1) was performed cephalometric tracing of Riedel ${ }^{13}$ briefly on the lateral cephalograms of each patient. The findings were analyzed on the basis of the two-way analysis of variance (ANOVA) in a factorial $2 \times 2$ (gender $x$ fissure and age $x$ fissure) using the Statistical Package for Social Sciences - SPSS (version 10.0 for Windows). The level of significance was set at $5 \%$.

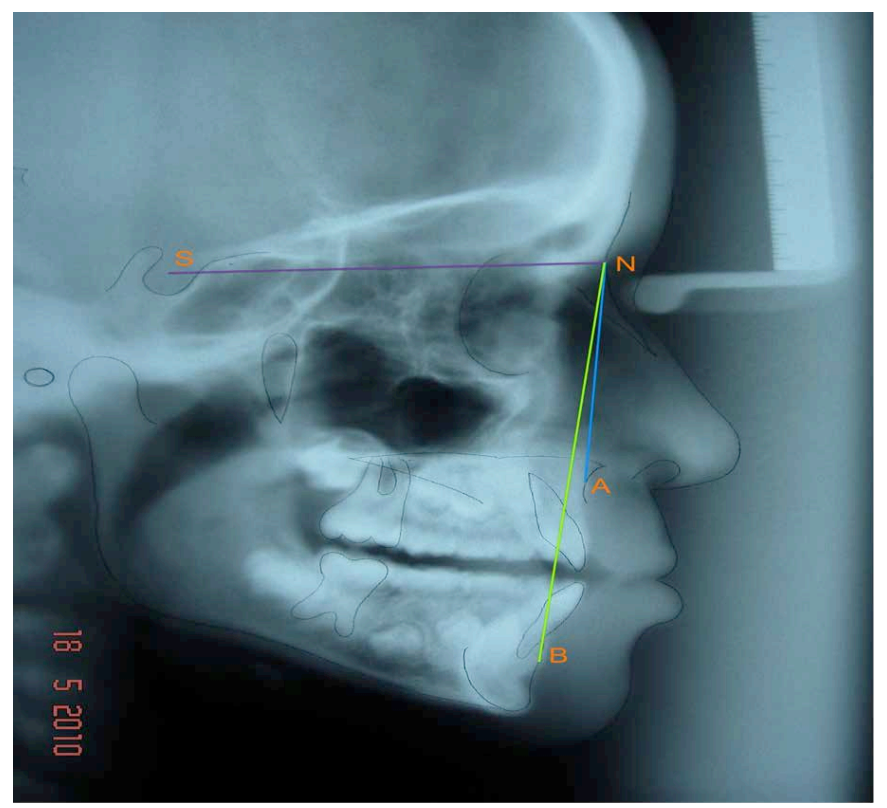

Figure 1. Getting the Angles SNA, SNB and ANB in lateral cephalometric radiographs. 
Development of the research was approved by the Ethical approval for the study was obtained from the Ethics Committee of the São Leopoldo Mandic, School of Dentistry, Campinas, São Paulo, Brazil in accordance with report No. 2010/0116, with a view to complying with the ethical principles contained in the Helsinki Declaration.

\section{RESULTS}

Sample distribution according to gender and age is presented in Table 1. Table 2 contains the results for SNA, SNB and ANB as a function of gender. There was no significant difference between gender and the interaction between both the gender $x$ cleft SNA angle ( $p=0.5258$ and $p=0.9981)$ and SNB angles ( $p=0.5548$ and $p=0.5253)$ and ANB $(p=0.2638$ and $p=0.7714)$. However, regarding the comparison between study and control groups, the angles SNA and SNB showed lower averages in both males and females in the group of cleft patients $(p<0.0001)$. The ANB angle also showed a significant difference between the two groups, showing higher averages for the group of cleft patients $(p<0.05)$ in both genders.

Table 1. Sample distribution according to gender and age.

\begin{tabular}{lccccc}
\hline & \multicolumn{2}{c}{$\begin{array}{c}\text { Cleft Group } \\
\text { (study group) }\end{array}$} & \multicolumn{2}{c}{$\begin{array}{c}\text { Non-cleft Group } \\
\text { (control group) }\end{array}$} & Total \\
\cline { 1 - 4 } Age & Females & Males & Females & Males & \\
\hline 6 years & 4 & 4 & 4 & 4 & 16 \\
7 years & 9 & 9 & 9 & 9 & 36 \\
8 years & 7 & 7 & 7 & 7 & 28 \\
9 years & 3 & 3 & 3 & 3 & 12 \\
Total & 23 & 23 & 23 & 23 & 92 \\
\hline
\end{tabular}

Table 2. Mean (standard deviation) for SNA, SNB and ANB as a function of gender (cleft group vs non-cleft group).

\begin{tabular}{|c|c|c|c|c|c|c|}
\hline \multirow[b]{2}{*}{ Gender } & \multicolumn{2}{|c|}{ SNA } & \multicolumn{2}{|c|}{ SNB } & \multicolumn{2}{|c|}{ ANB } \\
\hline & $\begin{array}{l}\text { Cleft } \\
\text { group }\end{array}$ & $\begin{array}{l}\text { Non-cleft } \\
\text { group }\end{array}$ & $\begin{array}{l}\text { Cleft } \\
\text { group }\end{array}$ & $\begin{array}{l}\text { Non-cleft } \\
\text { group }\end{array}$ & $\begin{array}{l}\text { Cleft } \\
\text { group }\end{array}$ & $\begin{array}{l}\text { Non-cleft } \\
\text { group }\end{array}$ \\
\hline Female & $\begin{array}{c}78.24 \\
(4.00) \\
\mathrm{Ba}\end{array}$ & $\begin{array}{c}81.94 \\
(1.55) \mathrm{Aa}\end{array}$ & $\begin{array}{c}74.71 \\
(3.73) \\
\mathrm{Ba}\end{array}$ & $\begin{array}{c}79.35 \\
(1.50) \mathrm{Aa}\end{array}$ & $\begin{array}{c}3.99 \\
(3.97) \\
\mathrm{Ba}\end{array}$ & $\begin{array}{c}2.59 \\
(1.92) \mathrm{Aa}\end{array}$ \\
\hline Male & $\begin{array}{c}78.70 \\
(5.10) \\
\mathrm{Ba}\end{array}$ & $\begin{array}{c}82.39 \\
(1.50) \mathrm{Aa}\end{array}$ & $\begin{array}{c}73.92 \\
(4.45) \\
\mathrm{Ba}\end{array}$ & $\begin{array}{c}79.37 \\
(1.32) \mathrm{Aa}\end{array}$ & $\begin{array}{c}4.83 \\
(3.51) \\
\mathrm{Ba}\end{array}$ & $\begin{array}{l}3.02 \\
(1.87) \mathrm{Aa}\end{array}$ \\
\hline Total & $\begin{array}{c}78.47 \\
(4.54) \\
B\end{array}$ & $\begin{array}{l}82.17 \\
(1.52) \mathrm{A}\end{array}$ & $\begin{array}{c}74.31 \\
(4.08) B\end{array}$ & $\begin{array}{c}79.36 \\
(1.40) \mathrm{A}\end{array}$ & $\begin{array}{c}4.38 \\
(3.72) \\
B\end{array}$ & $\begin{array}{c}2.80 \\
(1.89) \mathrm{A}\end{array}$ \\
\hline
\end{tabular}

Means followed by different letters are statistically different $(p \leq 0.05)$.

Table 3 presents the results for SNA, SNB and ANB depending on the age of the sample. For the SNA angle, there was no significant difference between ages $(p=0.5217)$ and the interaction between age $x$ cleft $(p=0.5153)$, as was observed in the SNB angle $(p=0.2638$ and $p=0.6327)$ and ANB $(p=0.0811$ and $p=0.8207)$. There was significant differences between study and control groups $(p<0.0001)$. The cleft group had lower mean SNA and SNB in all ages. For the angle ANB, the group with cleft had a higher average in all age groups $(p<0.05)$.

Table 3. Mean (standard deviation) for SNA, SNB and ANB as a result of age (cleft group vs non-cleft group).

\begin{tabular}{|c|c|c|c|c|c|c|}
\hline & \multicolumn{2}{|c|}{ SNA } & \multicolumn{2}{|c|}{ SNB } & \multicolumn{2}{|c|}{ ANB } \\
\hline Age & $\begin{array}{l}\text { Cleft } \\
\text { group }\end{array}$ & $\begin{array}{l}\text { Non-cleft } \\
\text { group }\end{array}$ & $\begin{array}{l}\text { Cleft } \\
\text { group }\end{array}$ & $\begin{array}{l}\text { Non-cleft } \\
\text { group }\end{array}$ & $\begin{array}{l}\text { Cleft } \\
\text { group }\end{array}$ & $\begin{array}{l}\text { Non-cleft } \\
\text { group }\end{array}$ \\
\hline 6 & $\begin{array}{c}79.76 \\
(3.74) \\
\mathrm{Ba}\end{array}$ & $\begin{array}{c}83.00 \\
(0.89) \mathrm{Aa}\end{array}$ & $\begin{array}{c}73.34 \\
(3.60) \\
\mathrm{Ba}\end{array}$ & $\begin{array}{c}79.06 \\
(1.33) \mathrm{Aa}\end{array}$ & $\begin{array}{c}6.43 \\
(2.32) \\
\mathrm{Ba}\end{array}$ & $\begin{array}{l}3.94 \\
(0.92) \mathrm{Aa}\end{array}$ \\
\hline 7 & $\begin{array}{c}78.08 \\
(3.71) \\
\mathrm{Ba}\end{array}$ & $\begin{array}{c}82.03 \\
(1.58) \mathrm{Aa}\end{array}$ & $\begin{array}{c}74.84 \\
(4.23) \\
\mathrm{Ba}\end{array}$ & $\begin{array}{c}79.36 \\
(1.40) \mathrm{Aa}\end{array}$ & $\begin{array}{c}3.81 \\
(3.94) \\
\mathrm{Ba}\end{array}$ & $\begin{array}{c}2.67 \\
(2.13) \mathrm{Aa}\end{array}$ \\
\hline 8 & $\begin{array}{c}77.56 \\
(6.19) \\
\mathrm{Ba}\end{array}$ & $\begin{array}{c}82.26 \\
(1.59) \mathrm{Aa}\end{array}$ & $\begin{array}{c}73.33 \\
(4.28) \\
\mathrm{Ba}\end{array}$ & $\begin{array}{c}79.28 \\
(1.55) \mathrm{Aa}\end{array}$ & $\begin{array}{c}4.24 \\
(4.11) \\
\mathrm{Ba}\end{array}$ & $\begin{array}{c}2.98 \\
(1.88) \mathrm{Aa}\end{array}$ \\
\hline 9 & $\begin{array}{c}80.03 \\
(3.32) \\
\mathrm{Ba}\end{array}$ & $\begin{array}{c}81.25 \\
(1.60) \mathrm{Aa}\end{array}$ & $\begin{array}{c}76.33 \\
(3.59) \\
\mathrm{Ba}\end{array}$ & $\begin{array}{c}79.97 \\
(1.27) \mathrm{Aa}\end{array}$ & $\begin{array}{c}3.70 \\
(3.44) \\
\mathrm{Ba}\end{array}$ & $\begin{array}{c}1.28 \\
(1.13) \mathrm{Aa}\end{array}$ \\
\hline Total & $\begin{array}{c}78.47 \\
(4.54) \mathrm{B}\end{array}$ & $\begin{array}{l}82.17 \\
(1.52) \mathrm{A}\end{array}$ & $\begin{array}{c}74.31 \\
(4.08) B\end{array}$ & $\begin{array}{c}79.36 \\
(1.40) \mathrm{A}\end{array}$ & $\begin{array}{c}4.38 \\
(3.72) \\
B\end{array}$ & $\begin{array}{c}2.81 \\
(1.89) \mathrm{A}\end{array}$ \\
\hline
\end{tabular}

Means followed by different letters are statistically different $(p \leq 0.05)$.

\section{DISCUSSION}

This study provides information about the effect of surgery during childhood on craniofacial development in Brazilian children. There was only one comparative study regarding the facial morphology of 2 groups of complete unilateral cleft lip and palate Brazilian children ${ }^{12}$. The findings of the present study showed that patients undergoing cleft repair surgery during childhood have a jaw development decreased compared to patients without cleft, corroborating other studies conducted in children and adults ${ }^{1,14-22}$. Regarding the interaction age $x$ cleft, the results were similar to those found by Gomide et al. ${ }^{16}$ who observed that retrusion of the maxilla is common feature of Brazilian individuals with cleft lip and palate in both genders, becoming more noticeable with advancing age in the pre and post-puberty ${ }^{19-21}$. In this study, the exception 
was observed at the age of 9 years showed an average within the prescribed values of normality, which can be regarded as casual as it is not the same patients were evaluated at $6,7,8$ and 9 years of age.

Some studies ${ }^{1,6,16,23-24}$ reported that the jaw of patients with cleft lip and palate who were operated on during childhood present similar behavior to the jaw since the early mixed dentition, which was also verified in this study. Silva Filho et al. ${ }^{6}$ observed that the jaw structure is changed in all sorts of cleft, and that, in the fissures involving the palate, retrognathia in adult patients is always present. However, some authors ${ }^{19,25-26}$ found no significant differences between the group of non-cleft and cleft in various age groups.

The present study is consistent with the findings of Meazinni et al. ${ }^{20}$ and Holst et al. ${ }^{21}$, who observed a progressive increase in the SNB angle over the years, but remained short when compared with the values of patients not affected by cleft lip and palate in the same age group.

In regards to the jaw relationship, a Class II skeletal pattern was found in males and a Class I skeletal pattern was observed in females, according to the default values of normality for the ANB angle. The mean of the cleft group showed that patients with unilateral completecleft lip and palate have a Class II skeletal relationship before the pubertal growth spurt. This finding is consistent with the findings of Zemann et al. ${ }^{23}$ who observed the same growth pattern in patients with 6 years of age. However, some authors ${ }^{16,18,24}$ have found a Class I skeletal relationship in various age groups and others $1,8,14-16,18,20-21,24$ have found a Class III skeletal pattern post-pubertal growth.

Regarding the assessment of age alone, it was observed that in all age groups between 6 and 9 years the average ANB angle in the group of cleft appeared beyond the values found in the control group. At 6 and 8 years, found a Class II skeletal pattern. At 7 and 9 years, these values are acceptable according to the default values

\section{REFERENCES}

1. Dogan S, Önçag G, Akin Y. Craniofacial development in children with unilateral cleft lip and palate. Br J Oral Maxillofac Surg. 2005;44(1):28-33. doi:10.1016/j.bjoms.2005.07.023

2. Aquino SN, Paranaíba LMR, Martelli DRB, Swerts MSO, Barros LM, Bonan PRF, et al. Study of patients with cleft lip and palate with consanguineous parents. Braz J Otorhinolaryngo. 2011;77(1):19-23. doi: 10.1590/S1808-86942011000100004 of normality in the group of cleft patients, suggesting a reasonable jaw relationship. The occurrence of Class II skeletal patterns at 6 and 8 years and Class I at 7 and 9 years can be explained by the fact that the pubertal growth spurt has not yet occurred; this way, the jaw had not yet reached its final position. According Meazinni et al. ${ }^{20}$ and Holst et al. ${ }^{21}$, from the pubertal growth spurt, the mandible shows a progressive development to earlier as the retrusion of the maxilla becomes more evident with advancing age $\mathrm{e}^{19-21}$ leading to a Class III skeletal relationship in adulthood ${ }^{1}, 14,15,19-21$.

Within the limitations of this study, future comparative and clinical studies using the same methodology and criteria are needed to verify skeletal patterns and potential for maxillofacial growth in children.

\section{CONCLUSION}

This study evaluated the craniofacial features of Brazilian children who had received surgery for unilateral complete cleft lip and palate compared with non-cleft children. The results showed that children with unilateral complete cleft lip and palate at ages 6, 7, 8 and 9 years, who underwent corrective surgery during childhood, showed deficiency in the development of maxilla and mandible and a Class II skeletal relationship.

\section{Collaborators}

RCS ROMANINI participated in the preparation, data collection and in writing the manuscript. $S$ VEDOVELLO, R RAITZ and MB FELIPPE-SILVA participated in discussion of the results and revising the manuscript critically. JLC JUNQUEIRA contributed to the design of the study and revising the manuscript critically. LB OLIVEIRA made substantial contributions to the design of the study and revising the manuscript critically.

3. Mosahebi A, Kangesu L. Cleft lip and palate. Plastic Surg 2006;24:33-7.

4. Mcheik JN, Sfalli P, Bondonny JN, Levard G. Early repair for infants with cleft lip and nose. Int J Pediatr Otorhi. 2006;70(10):178590. doi:10.1016/j.ijporl.2006.06.004

5. Semb G, Shaw WC. Facial growth after different methods of surgical intervention in patients with cleft lip and palate. Acta Odontol Scand. 1998;56(6):352-5. doi:10.1080/000163598428301 
6. Silva Filho OG, Normando ADC, Capelozza Filho L. Mandibular growth in patients with cleft lip and/or cleft palate: the influence of cleft type. Am J Orthod Dentofac Orthop. 1993;104(3):269-75.

7. Camporesi M, Baccetti T, Marinelli A, Defraia E, Franchi L. Maxillary dental anomalies in children with cleft lip and palate: a controlled study. Int J Paediatr Dent. 2010;20(6):442-50. doi: 10.1111/j.1365-263X.2010.01063.x

8. Liu R, Lu D, Wamalwa P, Li C, Hu H, Zou S. Craniofacial morphology characteristics of operated unilateral complete cleft lip and palate patients in mixed dentition. Oral Surg Oral Med Oral Pathol Oral Radiol Endod. 2011;11296):e-16-e25. doi: 10.1016/j.tripleo.2011.04.011

9. Mars M, Houston WJ. A preliminary study of facial growth and morphology in unoperated male unilateral cleft lip and palate subjects over 13 years of age. Cleft Palate J. 1990;27(1):7-10

10. Shetye PR, Evans CA. Midfacial morphology in adult unoperated complete unilateral cleft lip and palate patients. Angle Orthod. 2006;76(5):810-6

11. Rodrigues K, Sena MF de, Roncalli AG, Ferreira MAF. Prevalence of orofacial clefts and social factors in Brazil. Braz Oral Res. 2009;23(1):38-42. doi: 10.1590/\$1806-83242009000100007

12. Silva Filho $O G$, Calvano $F$, Assunção $A G$, Cavassan $A O$ Craniofacial morphology with complete unilateral cleft lip and palate: a comparison of two surgical protocols. Angle Orthod. 2001;71(4):274-84

13. Riedel RA. The relation of maxillary structures to cranium in malocclusion and in normal occlusion. Angle Orthod. 1952;22(3):142-5.

14. Enemark $\mathrm{H}$, Bolund $\mathrm{S}$, Jorgensen I. Evaluation of unilateral cleft lip and palate treatment: long term results. Cleft Palate J. 1990;27:354-61.

15. Semb G. A study of facial growth in patients with unilateral cleft lip and palate treated by the Oslo CLP team. Cleft Palate Craniofac J. 1991;28(1):1-21. doi: 10.1597/1545-1569(1991)028<0001:AS OFGI>2.3.CO;2

16. Gomide MR, Capelozza Filho L, Tovo AHS, Abdo RCC. Maxillomandibular relationship in children with cleft lip and palate. Rev Odontol Univ São Paulo. 1998;12(4):337-42. doi: 10.1590/S0103-06631998000400006

17. Zúñiga C, Miralles R, Carvajal R. Comparative study between children with and without cleft lip and cleft palate. Part 1: cephalometric analysis. Cleft Palate Craniofac J. 2000;37(3):2815. doi: 10.1597/1545-1569(2000)037<0281:CSBCWA>2.3.CO;2
18. Scheuer HA, Höltje WJ, Hasund A, Pfeifer G. Prognosis of facial growth in patients with unilateral complete clefts of the lip, alveolus and palate. J Craniomaxillofac Surg. 2001;29(4):198204. doi: $10.1054 / j \mathrm{cms} .2001 .0227$

19. Sasaki A, Takeshita S, Publico AS, Moss ML, Tanaka E, Ishino Y, et al. Finite element growth analysis for the craniofacial skeleton in patients with cleft lip and palate. Med Eng Phys. 2004;26(2):10918. doi: doi:10.1016/j.medengphy.2003.10.005

20. Meazzini MC, Giussani G, Morabito A, Semb G, Garattini G, Brusati R. A cephalometric intercenter comparison of patients with unilateral cleft lip and palate: analysis at 5 and 10 years of age and long term. Cleft Palate Craniofac J. 2008;45(6):654-60. doi: 10.1597/07-098.1

21. Holst Al, Holst S, Nkenke E, Fenner M, Hirschfelder U. Vertical and sagittal growth in patients with unilateral and bilateral cleft lip and palate - a retrospective cephalometric evaluation. Cleft Palate Craniofac J. 2009;46(5):512-20. doi: 10.1597/08-041.1

22. Del Guercio F, Meazzini MC, Garattini G, Morabito A, Semb G, Brusati R. A cephalometric intercentre comparison of patients with unilateral cleft lip and palate at 5 and 10 years of age. Eur J Orthod. 2010;32:24-7.

23. Zemann W, Mossböck R, Kärcher $H$, Kozelj V. Sagittal growth of the facial skeleton of 6-year-old children with a complete unilateral cleft of lip, alveolus and palate treated with two different protocols. J Craniomaxillofac Surg. 2007;35(8):343-9. doi:10.1016/j.jcms.2007.05.005

24. Heliövaara A, Rautio J. A comparison of craniofacial cephalometric morphology and the later need for orthognathic surgery in 6-year-old cleft children. J Craniomaxillofac Surg. 2011;39(3):173-6. doi: 10.1016/j.jcms.2010.03.020

25. Capelozza Filho L, Normando ADC, Silva Filho OG da Isolated influences of lip and palate surgery on facial growth: comparison of operated and unoperated male adults with UCLP. Cleft Palate Craniof J. 1996:33(1):51-6. doi: 10.1597/1545-1569(1996)033<0051:IIOLAP>2.3.CO;2

26. Ysunza A, Pamplona MC, Quiroz J, Yudovich M, Molina F, González S, et al. Maxillary growth in patients with complete cleft lip and palate, operated on around 4-6 months of age. Int J Pediatr Otorhi. 2010;74(5):482-5. doi:10.1016/j. ijporl.2010.01.024
Received on: $11 / 3 / 2014$

Final version resubmitted on: 7/5/2014 Approved on: 15/9/2014 
